\title{
Changes in Amount and Intracellular Distribution of Androgen Receptor in Human Foreskin as a Function of Age
}

\author{
Claus G. Roehrborn, John L. Lange, Fredrick W. George, and Jean D. Wilson \\ Departments of Internal Medicine, Surgery (Urology), and Cell Biology and \\ Anatomy, The University of Texas Health Science Center at Dallas, Dallas, Texas 75235
}

\begin{abstract}
To provide insight into the factors that control growth of the penis we measured the amount and intracellular distribution of specific high affinity androgen receptor in foreskins obtained at circumcision from 49 males varying in age from newborn to 59 yr. Total (cytosolic plus nuclear extract) androgen receptor decreased from $\sim \mathbf{4 0} \mathrm{fmol} / \mathrm{g}$ tissue weight in newborn foreskins to $\sim 25 \mathrm{fmol} / \mathrm{g}$ by $1 \mathrm{yr}$ of age. The amount of receptor rose in childhood to $\sim 180 \mathrm{fmol} / \mathrm{g}$ in the late teenage years and fell thereafter to $\sim 20-40 \mathrm{fmol} / \mathrm{g}$ in men older than $40 \mathrm{yr}$. The amount of receptor in the nuclear fraction increased at the time of puberty and subsequently decreased in parallel with the decline in total receptor level. These changes in androgen-receptor amount are similar when expressed per milligram DNA or per milligram protein.
\end{abstract}

\section{Introduction}

Although androgens control both the formation of the male organs of accessory reproduction during embryogenesis and the growth and maturation of these tissues at the time of puberty (1), the factors that modulate androgen action in androgen-dependent tissues are poorly understood. Because of the accessibility of human foreskin for study, the androgen control of human penile growth has been scrutinized by several groups. Dihydrotestosterone is the androgen that mediates the formation of the penis in the embryo; the fetal anlagen of the penis (the urogenital tubercle) contains both $5 \alpha$-reductase enzyme for the conversion of testosterone to dihydrostestosterone (2) and high affinity androgen receptor, which mediates dihydrotestosterone action in the tissue (3). Furthermore, mutations that seriously impair testosterone biosynthesis, dihydrotestosterone formation, or the function of the androgen receptor cause defects in penile development that vary, depending on severity of the defect, from complete failure of male development to incomplete formation of the urethra (hypospadias) in otherwise normal men (4).

Penile growth at the time of male puberty is initiated by the rise in plasma testosterone to adult male levels $(5,6)$; the pubertal growth process, like that of differentiation, is probably mediated by formation of dihydrotestosterone in the tissue itself (7), and dihydrotestosterone, in turn, acts through the same high affinity androgen receptor as in the embryo (3). Additional hormones including growth hormone and thyroxine also appear to be in-

This work has been published in part in abstract form (1986. Clin. Res. 34:715A).

Received for publication 13 June 1986.

J. Clin. Invest.

(c) The American Society for Clinical Investigation, Inc. $0021-9738 / 87 / 01 / 0044 / 04 \$ 1.00$

Volume 79, January 1987, 44-47 volved in the control of penile growth, possibly acting in a permissive fashion (8). Once some limit is reached at around age 17-18 growth ceases despite continued (or enhanced) androgen stimulation $(5,6)$. The nature of the factors that limit this hormone-mediated growth process (presumably genetic in origin) and the mechanism by which they function are poorly understood. For example, although the activity of $5 \alpha$-reductase in foreskin declines significantly as penile growth ceases in the late teenage years (7), this decline is probably not causal in the decreased growth.

The high affinity androgen receptor in human foreskin has been studied by several investigators, using techniques that have provided different ranges of normal values (9-13), and no clear relation has been established between receptor levels and the capacity of the tissue for growth. In hopes of providing insight into androgen-mediated growth of the penis, we have reinvestigated the content and the intracellular distribution of the androgen receptor in human foreskin from men of varying ages, using $\left[{ }^{3} \mathrm{H}\right]$ methyltrienolone as the binding ligand.

\section{Methods}

[17 $\alpha$-methyl- $\left.{ }^{3} \mathrm{H}\right]$ methyltrienolone $(\mathrm{R} 1881)(86 \mathrm{Ci} / \mathrm{mmol})$ and nonradioactive methyltrienolone were purchased from New England Nuclear (Boston, MA). All other nonradioactive steroids were obtained from Steraloids Inc. (Pawling, NY).

Foreskins were obtained at elective circumcisions, placed in ice-cold normal saline, brought to the laboratory within $2-3 \mathrm{~h}$, and frozen in liquid nitrogen. At the time of the experiment, the tissue was taken out of the freezer, manually cut while frozen into small pieces, and pulverized in liquid nitrogen for $4 \mathrm{~min}$ at the highest setting in a freezer mill (SPEX Industries, Metuchen, NJ). The powder was weighed and mixed with TEMSH buffer ( $10 \mathrm{mM}$ Tris at $\mathrm{pH} 7.4$ containing $1.5 \mathrm{mM}$ EDTA, $0.1 \%$ monothioglycerol, and $10 \mathrm{mM} \mathrm{Na} \mathrm{MoO}_{4}$ ) at a ratio of 1-3:1 vol/wt. The mixture was homogenized with 10 strokes of the loose pestle of a Dounce homogenizer, and 0.2-ml aliquots of the homogenate were removed for DNA measurement by the method of Burton (14).

The remainder of the homogenate was centrifuged at $250,000 \mathrm{~g}$ for $30 \mathrm{~min}$, and the supernatant (cytosol) was aspirated. The pellet was resuspended in $2 \mathrm{ml}$ TEMSH buffer containing $500 \mathrm{mM} \mathrm{KCl}$. The tube was immersed in ice, and subjected to one 10-s homogenization using a Polytron tissue homogenizer (Kinematica $\mathrm{GmbH}$, Luzern, Switzerland) at a power setting of 8 . The sample was then subjected to a 10 -s sonication (Biosonik III; Bronwill Scientific, Rochester, NY) at an intensity of 30. The homogenate was centrifuged at $250,000 \mathrm{~g}$ for $30 \mathrm{~min}$; the supernatant was aspirated and designated nuclear extract. Protein content was measured in both cytosol and nuclear extract by the method of Lowry et al. (15).

Aliquots of the cytosol and nuclear extract were incubated for $1 \mathrm{~h}$ at $4^{\circ} \mathrm{C}$ with $5 \mathrm{nM}\left[{ }^{3} \mathrm{H}\right]$ methyltrienolone in the presence of $2.5 \mu \mathrm{M}$ triamcinolone acetonide and in the presence or absence of $0.5 \mu \mathrm{M}$ nonradioactive methyltrienolone. Aliquots $(250 \mu \mathrm{l})$ of cytosol or nuclear extract were then layered on 5.0- $\mathrm{ml} \mathrm{5-20 \%} \mathrm{sucrose} \mathrm{gradients} \mathrm{(prepared} \mathrm{in} 10$ $\mathrm{mM}$ TEMSH buffer and 10\% vol/vol glycerol) containing $5 \mathrm{nM}$ $\left[{ }^{3} \mathrm{H}\right]$ methyltrienolone plus $2.5 \mu \mathrm{M}$ triamcinolone acetonide plus or minus 
$0.5 \mu \mathrm{M}$ methyltrienolone (radioactive gradients). The gradients were centrifuged at $200,000 \mathrm{~g}$ for $18 \mathrm{~h}$ in an SW 50.1 rotor (Beckman Instruments Inc., Palo Alto, CA). Fractions $(0.2 \mathrm{ml})$ were collected using a 690 density gradient fractionator (ISCO, Lincoln, NE). Bound and free hormone were separated in postcentrifugation fractions by the hydroxylapatite procedure that was previously described (3). The washed hydroxylapatite pellet was extracted with $1 \mathrm{ml}$ ethanol at room temperature for $30 \mathrm{~min}$ and centrifuged at $1,500 \mathrm{~g}$ for $5 \mathrm{~min}$; the supernatant was decanted into vials for measurement of radioactivity in a liquid scintillation counter.

Parallel aliquots of the incubated fractions were kept $18 \mathrm{~h}$ at $4^{\circ} \mathrm{C}$, and a direct hydroxylapatite assay of bound radioactivity was performed (3) at the time of assay of the gradient fractions. In 19 experiments, a direct charcoal assay was also performed after overnight incubation; 50 $\mu \mathrm{l}$ of dextran-charcoal suspension were added to $0.2-\mathrm{ml}$ fractions, and the tubes were shaken at $4^{\circ} \mathrm{C}$ for $5 \mathrm{~min}$ and centrifuged at $5,000 \mathrm{~g}$ for $30 \mathrm{~min}$. The supernatant was aspirated and assayed for radioactivity.

\section{Results}

The techniques for extracting the androgen receptor for foreskin have been adapted from the studies of Fichman et al. (11). The androgen receptors were measured by sucrose density gradient methods using radioactive gradients as well as a direct binding assay. In both instances an hydroxylapatite procedure was used to separate bound from free hormone (3). The sequential extraction in buffers of low and high molarity allowed the separation of fractions that consisted predominantly of cytosol and nuclei. Reextraction of the pellet with either TEMSH buffer or $500 \mathrm{mM} \mathrm{KCl}$ in TEMSH buffer resulted in a $12-15 \%$ increase in receptor (results not shown). Because we wished to assay the amount of receptor under varying conditions of receptor occupancy by endogenous steroids we used radioactive gradients that allow exchange between receptor-bound and free steroid during the entire period of centrifugation, and in the direct assay we incubated the samples overnight (3). Under these conditions, it made no difference whether the samples were incubated for $1 \mathrm{~h}$ (shorter periods were not examined) or $24 \mathrm{~h}$ before applying them to density gradients (results not shown). As previously reported for human prostate (16) and foreskin (11-13), freezing the tissue in liquid nitrogen for as long as $\mathbf{3} \mathrm{d}$ had no effect on the receptor levels (Table I). Methyltrienolone was used as the binding ligand because it is not metabolized at a significant rate by either cytosol or nuclear extracts (results not shown) and because it binds weakly to testosterone-binding globulin of plasma. The amount of receptor was assayed under saturating conditions of binding ligand (5 $\mathrm{nM}$ ) (Fig. 1).

Table I. Effect of Storage in Liquid Nitrogen on the Recovery of Androgen Receptor

\begin{tabular}{lll}
\hline & Androgen receptor & \\
\cline { 2 - 3 } Tissue component & Fresh & Frozen \\
\hline & fmol/g tissue & \\
Cytosol & 20 & 24 \\
Nuclear & 38 & 42 \\
& & \\
\hline
\end{tabular}

The foreskin from a 23-yr-old man was divided into two aliquots. One portion $(1.8 \mathrm{~g})$ was processed immediately, and one portion $(3.9 \mathrm{~g})$ was frozen in liquid nitrogen for $72 \mathrm{~h}$ before processing as described in the text. Binding of $\left[{ }^{3} \mathrm{H}\right]$ methyltrienolone was assessed by the direct hydroxylapatite assay.

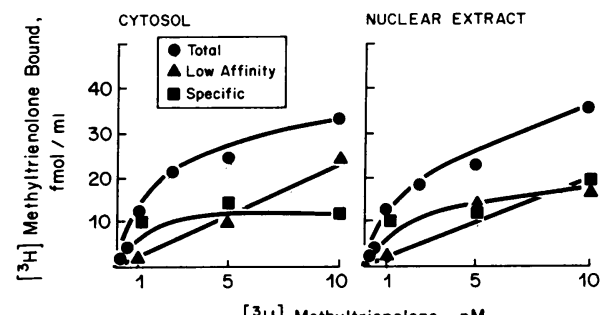

$\left[{ }^{3} \mathrm{H}\right]$ Methyltrienolone, $\mathrm{nM}$

Figure 1. Binding of $\left[{ }^{3} \mathrm{H}\right]$ methyltrienolone by cytosol and nuclear extracts as a function of methyltrienolone concentration. Cytosol $(9.8$ $\mathrm{mg}$ protein $/ \mathrm{ml}$ ) and nuclear extract $(2.7 \mathrm{mg}$ protein $/ \mathrm{ml})$ were prepared from foreskin from a 19-yr-old man, and the androgen receptor was assessed using the direct hydroxylapatite assay at varying concentrations of $\left[{ }^{3} \mathrm{H}\right]$ methyltrienolone as described in the text.

Hydroxylapatite absorption was used for the assay of the $\left[{ }^{3} \mathrm{H}\right]$ methyltrienolone-receptor complexes because in previous studies of the human prostate we had observed the presence of a methyltrienolone-binding protein that is detected by charcoal assay but not by the hydroxylapatite technique (16). With the hydroxylapatite method, specific methyltrienolone binding in foreskin cytosol is localized to the 4 and $9 S$ regions of the density gradient, whereas in the high salt nuclear extracts it was always in the $4 \mathrm{~S}$ regions (Fig. 2). Androgen receptor levels obtained using the density gradient assay were similar to those obtained

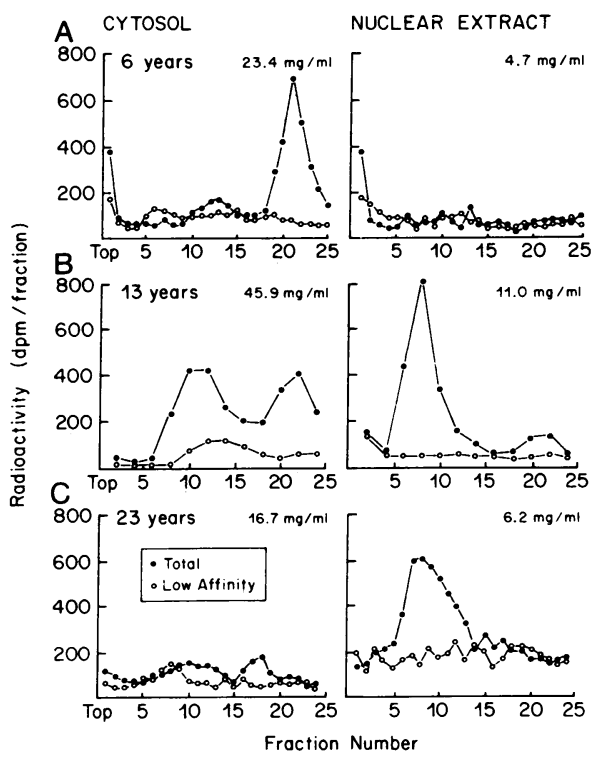

Figure 2. Gradient density centrifugation of cytosolic and nuclear extracts of human foreskin in 5-20\% sucrose containing $5 \mathrm{nM}$ $\left[{ }^{3} \mathrm{H}\right]$ methyltrienolone. $(A)$ Cytosol $(23.4 \mathrm{mg}$ protein $/ \mathrm{ml})$ and nuclear extract $(4.7 \mathrm{mg}$ protein $/ \mathrm{ml})$ were prepared from foreskin from a 6-yrold boy. (B) Cytosol (46 mg protein/ml) and nuclear extract (11.0 mg protein $/ \mathrm{ml}$ ) were prepared from foreskin from a 13-yr-old boy. $(C)$ Cytosol $(16.7 \mathrm{mg}$ protein $/ \mathrm{ml})$ and nuclear extract $(2.9 \mathrm{mg}$ protein $/ \mathrm{ml})$ were prepared from foreskin from a 23 -yr-old man. The extracts were incubated with $5 \mathrm{nM}\left[{ }^{3} \mathrm{H}\right]$ methyltrienolone for $1 \mathrm{~h}$, and $0.25-\mathrm{ml}$ aliquots were layered over 5-20\% sucrose gradients containing $2.5 \mu \mathrm{M}$ triamcinolone acetonide and $5 \mathrm{nM}$ and/or $5 \mu \mathrm{M}\left[{ }^{3} \mathrm{H}\right]$ methyltrienolone and centrifuged at $250,000 \mathrm{~g}$ for $18 \mathrm{~h}$. After fractionation of the gradients, each fraction was treated with hydroxylapatite and assayed for ${ }^{3} \mathrm{H}$ as described in the text. 


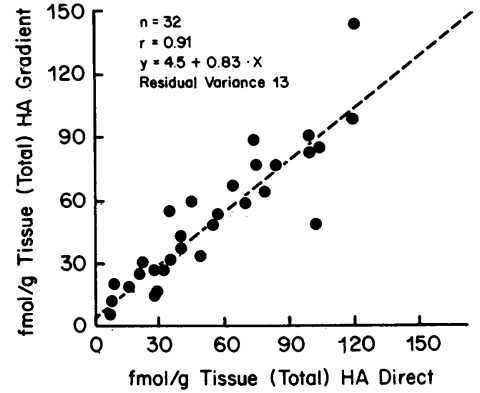

with the direct hydroxylapatite assay (correlation coefficient $=0.91, n=32$ ) (Fig. 3). In contrast, values obtained by us with a charcoal assay did not correlate well with either the direct hydroxylapatite assay or the gradient density analysis (results not shown). The values obtained with the hydroxylapatite assay for the amount of androgen receptor in foreskin are similar to those reported by Svenson and Snochowski (10) and by Coulam et al. (12), but lower than those reported by Fichman et al. (11).

The specificity of the binding phenomena was examined by comparing the displacement of methyltrienolone binding by a variety of steroids (Fig. 4). Binding in the cytosol and nuclear extracts was displaced by a hundredfold excess of methyltrienolone and dihydrotestosterone. Testosterone, $5 \alpha$-androstane$3 \alpha, 17 \beta$-diol ( $3 \alpha$-androstanediol), and progesterone were weak or ineffective competitors for $\left[{ }^{3} \mathrm{H}\right]$ methyltrienolone binding.

Binding as a function of age was analyzed as the amount of specific methyltrienolone binding per gram of tissue, per milligram of tissue protein, and per milligram of tissue DNA. The trends were similar for the three methods. For comparative purposes individual values were plotted per gram of tissue weight for cytosol, nuclear extract, and total binding (i.e., the sum of cytosol and nuclear binding) (Fig. 5). The mean values plus and minus standard deviations for various age groups are shown in Fig. 6. The amount of receptor in cytosol in newborn infants averaged $\sim 30 \mathrm{fmol} / \mathrm{g}$ tissue and fell to $\sim 20 \mathrm{fmol} / \mathrm{g}$ tissue by 1 $\mathrm{yr}$ of age, increased to a maximum of $\sim 80 \mathrm{fmol} / \mathrm{g}$ tissue in the teenage years, and then decreased by age 30 to values not significantly different than in early infancy. In the nuclear extract,

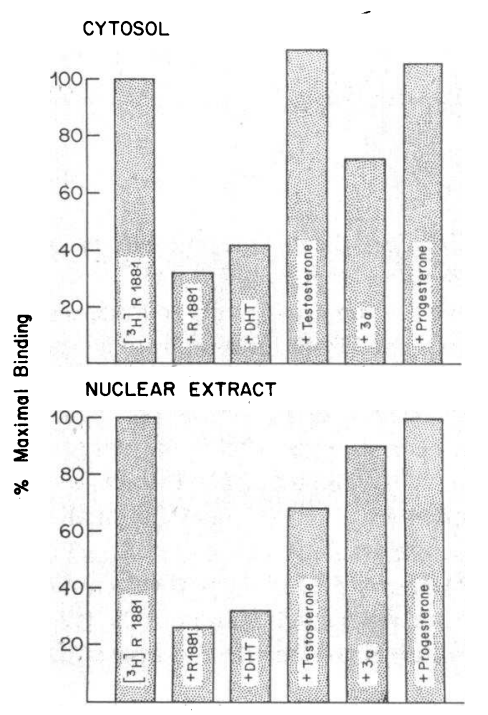

Figure 4. Displacement of $\left[{ }^{3} \mathrm{H}\right]$ methyltrienolone $\left({ }^{3} \mathrm{H}-\mathrm{R}\right.$ 1881 ) binding by various steroids. 0.1-ml aliquots of cytosol $(39 \mathrm{mg}$ protein $/ \mathrm{ml})$ and nuclear extract $(8.2 \mathrm{mg}$ protein $/ \mathrm{ml}$ ) from foreskin from a 19-yr-old man were incubated for $18 \mathrm{~h}$ at $4^{\circ} \mathrm{C}$ with $5 \mathrm{nM}\left[{ }^{3} \mathrm{H}\right]$ methyltrienolone alone or with 0.5 $\mu \mathrm{M}$ methyltrienolone $(\mathrm{R}$ 1881), dihydrotestosterone (DHT), testosterone, $3 \alpha$-androstanediol $(3 \alpha)$, or progesterone. Binding was assessed by the direct hydroxylapatite assay as described in the text.

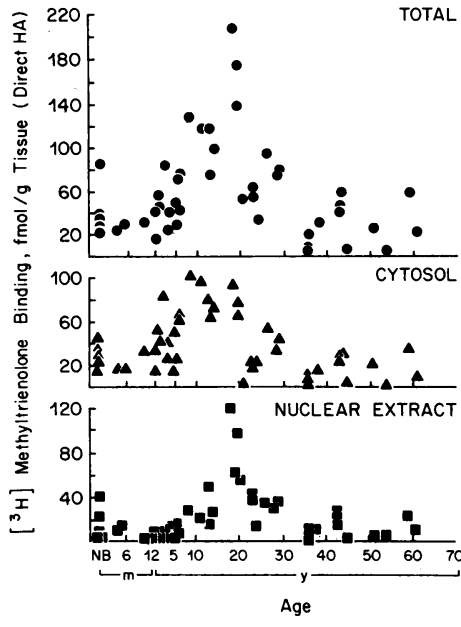

Figure 5. Foreskin androgen receptor as a function of age. The data are expressed as femtomoles of specific binding of $\left[{ }^{3} \mathrm{H}\right]$ methyltrienolone per gram weight of tissue using the direct hydroxylapatite assay for cytosol, nuclear extract, and for the sum of cytosol and nuclear extract (total).

receptor was measurable in the newborn, fell to a low level between 1 mo and the onset of puberty, increased to a maximum of $\sim 100 \mathrm{fmol} / \mathrm{g}$ of tissue by age 16-20, and then decreased on average in later life to levels of $<15 \mathrm{fmol} / \mathrm{g}$ (Fig. 6). Total androgen receptor values are similar in pattern to those of the cytosol fraction. The ratio of nuclear to cytosolic androgen receptor is shown in Fig. 6. Most of the receptor is present in cytosol during childhood. The nuclear fraction increases at puberty and after age 20 accounts on average for about half of the total receptor. The findings in nuclei are in agreement with those of Fichman et al. (11) and suggest that physiological amounts of androgen anchor the receptor in the nuclei.

\section{Discussion}

The techniques utilized in this study make it possible to assess two components of androgen receptor in human foreskin-one fraction that can be extracted in low ionic strength buffers and another that is extracted with high salt. We assume, along with

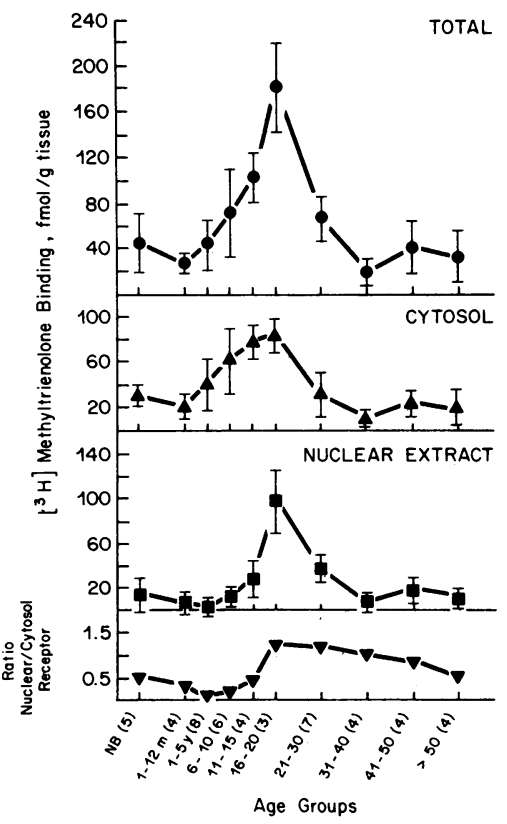

Figure 6. Mean levels of foreskin androgen receptor in nuclear and cytosol as a function of age. The results shown in Fig. 5 have been grouped as newborn, age 1-12 mo, age 1-5 yr, 6$10 \mathrm{yr}, 11-15 \mathrm{yr}, 16-20$ $\mathrm{yr}, 21-30 \mathrm{yr}, 31-40 \mathrm{yr}$, $41-50 \mathrm{yr}$, and $>50 \mathrm{yr}$. The data are expressed as means plus or minus the SE of the mean. The number of samples are shown in parentheses. In the bottom panel the ratio of mean nuclear to mean cytoplasmic receptor has been plotted for each age group. 
Fichman et al. (11), that the material extracted by high salt is predominantly occupied receptor within nuclei. Whether the fraction extracted by low salt represents unoccupied receptor from cytosol or from some other tissue component is not clear. Although the unoccupied estradiol receptor appears to be present mainly in the nucleus $(17,18)$, the intracellular location of the unoccupied androgen receptor has not been defined. The combination of overnight incubation with $\left[{ }^{3} \mathrm{H}\right]$ methyltrienolone (or centrifugation in gradients containing $\left[{ }^{3} \mathrm{H}\right]$ methyltrienolone) followed by adsorption of the androgen-receptor complex to hydroxylapatite circumvents the problem of contamination of tissues with testosterone-binding globulin from plasma and minimizes the chance of measuring methyltrienolone-binding proteins that may be receptor degradation products (16).

With the techniques used in the present study we have observed a striking change in total receptor content with age. The concentration falls between the newborn period and $1 \mathrm{yr}$ of age, then increases to reach a maximum level by age 17-18, and then falls again with progressive age. This curve has features in common with the growth curve of the penis itself, which ceases after age 17-18 $(5,6)$. On the one hand the decrease in the amount of androgen receptor could be causally linked to the cessation of growth, or alternatively the decrease could be a secondary consequence of the cessation of growth. It is of interest that a similar decrease with age in the content of the androgen receptor has been reported for rat penis (19).

Although up-regulation of human androgen receptors by androgens has been observed in cultured foreskin fibroblasts (20), the finding that the total amount of androgen receptor increases before age 10 and hence before the period of androgen-mediated growth suggests that the level of androgen receptor is not controlled solely by testicular androgens. In some tissues the amount of androgen receptor is controlled by estrogen (21). Whether the level of androgen receptor in prepubertal human foreskin is influenced by estrogen, by other hormones such as thyroxine or growth hormone, or by nonhormonal factors, is unknown. Nevertheless, the net consequence of the increase in the level of androgen receptor in the tissue may be to prime the tissue for the increase in androgen levels at puberty, and hence for androgen-mediated growth.

The present findings confirm the observations of Fichman et al. (11) that the amount of salt-extractable androgen receptor correlates with the plasma testosterone level, namely it is measurable in the newborn, is virtually undetectable between 1 mo of age and the onset of puberty, and thereafter accounts on average for about half the receptor in the tissue. Presumably, this fraction is largely occupied receptor that is anchored in the nucleus and is not extracted when the tissue is homogenized in buffers of low molarity.

On the basis of these studies it is not possible to deduce what controls the level of the androgen receptor in the penis. Nor is it possible to be certain whether the levels of androgen receptor are rate limiting either for pubertal growth or for the cessation of growth after puberty. Elucidation of the mechanisms responsible for the regulation of the tissue receptor level would make it possible to design studies to define the role of the androgen receptor in this process.

\section{Acknowledgment}

This work was supported in part by grant AG-00306 from National Institutes of Health.

\section{References}

1. Wilson, J. D. 1975. Metabolism of testicular androgens. In Handbook of Physiology, Section 7: Endocrinology. Vol. V, Male Reproductive System, Ch. 25. R. O. Greep and E. B. Astwood, editors. American Physiological Society, Washington, D. C. 491-508.

2. Siiteri, P. K., and J. D. Wilson, 1974. Testosterone formation and metabolism during male sexual differentiation in the human embryo. $J$. Clin. Endocrinol. Metab. 38:113-125.

3. George, F. W., and J. F. Noble. 1984. Androgen receptors are similar in fetal and adult rabbits. Endocrinology. 115:1451-1458.

4. Griffin, J. E., and J. D. Wilson. 1986. Disorders of sexual differentiation. In Campbell's Urology. P. C. Walsh, R. F. Gittes, A. D. Perlmutter, and R. A. Stamey, editors. W. B. Saunders, Philadelphia. 18191855.

5. Schonfeld, W. A., and G. W. Beebe. 1942. Normal growth and variation in the male genitalia from birth to maturity. J. Urol. 48:759777.

6. Schonfeld, W. A. 1943. Primary and secondary sexual characteristics: study of their development in males from birth through maturity, with biometric study of penis and testes. Am. J. Dis. Child. 65:535-549.

7. Wilson, J. D., and J. D. Waiker. 1969. The conversion of testosterone to $5 \alpha$-androstan-17 $\beta$-ol-3-one (dihydrotestosterone) by skin slices of man. J. Clin. Invest. 48:371-379.

8. Walsh, P. C., J. D. Wilson, T. D. Allen, J. D. Madden, J. C. Porter, W. B. Neaves, J. E. Griffin, and W. E. Goodwin. 1978. Clinical and endocrinological evaluation of patients with congenital microphallus. $J$. Urol. 120:90-95.

9. Evain, D., M. O. Savage, and E. Binet. 1977. A specific and rapid determination of human skin dihydrotestosterone cytosol receptor. $J$. Clin. Endocrinol. Metab. 45:363-366.

10. Svensson, J., and M. Snochowski. 1979. Androgen receptor levels in preputial skin from boys with hypospadias. J. Clin. Endocrinol. Metab. 49:340-345.

11. Fichman, H. R., L. M. Nyberg, P. Bujnovszky, T. R. Brown, and P. C. Walsh. 1981. The ontogeny of the androgen receptor in human foreskin. J. Clin. Endocrinol. Metab. 52:919-923.

12. Coulam, C. B., A. J. Razel, P. P. Kelalis, J. Svensson, and T. C. Spelsberg. 1983. Androgen receptor in human foreskin. II. Characterization of the receptor from hypospadiac tissue. Am. J. Obstet. Gynecol. 147:513-520.

13. Razel, A. J., J. Svensson, T. C. Spelsberg, and C. B. Coulam. 1985. The androgen receptor in normal human foreskin. I. Stabilization and identification of two receptor subunits. Am. J. Obstet. Gynecol. 153: 410-416.

14. Burton, K. 1956. A study of the conditions and mechanisms of the diphenylamine reaction for the colorimetric estimation of desoxyribonucleic acid. Biochem. J. 62:315-323.

15. Lowry, O. H., N. J. Rosebrough, A. L. Farr, and R. J. Randall. 1951. Protein measurement with folic phenol reagent. J. Biol. Chem. 193:265-275.

16. Wilbert, D. M., J. E. Griffin, and J. D. Wilson. 1983. Characterization of the cytosol androgen receptor of the human prostate. $J$. Clin. Endocrinol. Metab. 56:113-120.

17. King, W. J., and G. L. Greene. 1984. Monoclonal antibodies localize oestrogen receptor in the nuclei of target cells. Nature (Lond.). 307:745-747.

18. Welshons, W. V., M. E. Liberman, and J. Gorski. 1984. Nuclear localization of unoccupied oestrogen receptors. Nature (Lond.). 307:747749.

19. Rafjer, J., P. C. Namkung, and P. H. Petra. 1980. Identification, partial characterization and age-related changes of a cytoplasmic androgen receptor in the rat penis. J. Steroid Biochem. 13:1489-1492.

20. Kaufman, M., L. Pinsky, and R. Feder-Hollander. 1981. Defective up-regulation of the androgen receptor in human androgen insensitivity. Nature (Lond.). 293:735-737.

21. Moore, R. J., J. M. Gazak, and J. D. Wilson. 1979. Regulation of cytoplasmic dihydrotestosterone binding in dog prostate by $17 \beta$-estradiol. J. Clin. Invest. 63:351-357. 